\title{
Hidrelétricas no desenvolvimento urbano e territorial de São Paulo
}

\author{
Dossier EletromemóRIA: PAISAGEM E HistóRIA
}

\section{Débora Marques de Almeida Nogueira}

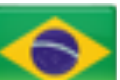

Arquiteta e urbanista, Mestre em Engenharia Urbana, Doutora em Engenharia Civil. Pós-doutoranda do Departamento de Recursos Hídricos (FEC-Unicamp). Pesquisadora do Labore (Unicamp). São Carlos [SP] Brasil.<dmortati@terra.com.br>.

\section{André Munhoz de Argollo Ferrão}

Engenheiro civil, Arquiteto e urbanista, Mestre em Engenharia Agrícola, Doutor em Arquitetura e Urbanismo. Professor Livre Docente do Departamento de Recursos Hídricos (FEC-Unicamp). Coordenador do Labore (Unicamp). Campinas [SP] Brasil. <argollo@fec.unicamp.br>.

\section{Resumo}

A partir da concepção de paisagem cultural e de uma análise da implantação das usinas hidrelétricas do estado de São Paulo de 1890 a 1930, pretende-se analisar os impactos no desenvolvimento das cidades ecléticas no âmbito da industrialização e dos melhoramentos urbanos, relacionando as alterações nos modos de vida e o rompimento com o mundo rural, associados à difusão da energia elétrica. A tese é que a chegada da eletricidade e suas usinas foi um dos elementos definidores da paisagem industrial do território de São Paulo, aqui demonstrada através da influência que as 118 primeiras centrais hidrelétricas que surgiram no estado tiveram no aparecimento e desenvolvimento das cidades paulistas neste período e que a disponibilidade de energia foi fundamental para a mudança da economia rural do café para a da urbano-industrial no Brasil.

\section{Palavras-chave}

Central hidrelétrica, urbanismo, patrimônio industrial, cidades, estado de São Paulo, Brasil.

\section{Hydroelectric plants in the urban and territorial development of São Paulo State}

\begin{abstract}
From the concept of cultural landscape and analysis of the hydroelectric plants implantation in São Paulo State, from 1890 to 1930, we intend to analyze the impacts of the electricity in the development and industrialization in the cities improvements, relating changes in their way of living and the rupture to the rural world, associated with the electricity distribution. The thesis is that the arrival of electricity and its plants was one of the elements who defined the industrial landscape in Sao Paulo State territory, demonstrated here through the influence of the 118 first hydroelectric plants in the state had in the development of the cities in that period and also, how much the availability of energy was the key to changing rural economy of coffee for the urban-industrial in Brazil.
\end{abstract}

\section{Keywords}

Hydroelectric plant, urbanism, industrial heritage, cities, São Paulo State, Brazil. 


\section{Introdução}

O desenvolvimento do estado de São Paulo pode ser contextualizado a partir do conceito de paisagem cultural tendo em vista o patrimônio formado pelo conjunto de 118 centrais hidrelétricas pioneiras instaladas no seu território de 1890 a 1930. A implantação de tamanha quantidade de hidrelétricas, num período de tempo relativamente curto e num único sítio constitui um empreendimento arrojado e bem sucedido, caso único no mundo, que contribuiu para a criação e o desenvolvimento de cidades modernas que exerceram forte influência sobre a industrialização do estado mais rico do Brasil.

Focamos [...] nas transformações da paisagem rural e urbana a partir da produção cafeeira e seus aparatos, com o objetivo de analisar como a linha divisória entre o território rural e urbano vai se diluindo na medida em que o café coloca a necessidade de uma base urbana para seu desenvolvimento. Neste processo, o urbano, como modo de vida, vai caracterizando e introduzindo novos paradigmas no espaço rural, que podem ser observados na arquitetura e nos meios de produção (ARGOLLO FERRÃO et al., 2008).

As cidades paulistas que surgem no fim do século XIX refletiam a modernidade, principalmente a partir de uma nítida influência europeia; e estavam invariavelmente baseadas em três ideias que traduziam a referência do urbanismo oitocentista: fomentar a limpeza e higienização, facilitar a fluidez da circulação quer do tráfego, das águas ou da energia, e regulamentar as edificações.

Café, modernidade e industrialização constituíram o mote para a transformação da paisagem do interior paulista, culminando na construção de sua paisagem atual, alicerçada nas referências do espaço urbano ou de um território urbanizado, diluindo, ou pelo menos deixando mais permeável, os limites entre um espaço rural (campo) altamente produtivo e um espaço urbano (cidade) dinâmico, baseado nos ideais de modernidade (ARGOLLO FERRÃO et al., 2008).

As "cidades elétricas" paulistas ampliavam seus espaços de convívio social e cultural, antes restritos basicamente ao entorno das igrejas, criando espaços laicos que representavam a modernidade, como os teatros e os clubes literários. Concomitantemente eram instaladas, desde fins do século XIX, as "melhorias" urbanas, tais como a iluminação pública, rede de água e esgoto, hospitais, os passeios públicos, sistemas de comunicação, transporte público e a ferrovia; numa clara intenção de se equiparar com as modernas cidades europeias.

Os grandes fazendeiros de café investiam em alguns segmentos urbanos, dentre os quais a produção de equipamentos coletivos que, até o início do século XX, serviam a praticamente toda a população das pequenas e médias cidades do interior de São Paulo.

A partir do final do século XIX praticamente todas as cidades paulistas tomaram alguma medida quanto a iluminação pública. Em trinta anos, todas já recebiam energia elétrica, sendo que nos primeiros dez anos, algumas dessas cidades já haviam sido eletrificadas.

A hidreletricidade foi a base para a disseminação da iluminação pública e do transporte urbano - os bondes - nas cidades mais desenvolvidas do Brasil, sendo rapidamente implantada nas cidades paulistas, como parte dos "melhoramentos" urbanos necessários às modernizações por que estas abastadas cidades ansiavam.

O modo de vida urbano adquire o significado de modernidade, e morar na cidade passa a ser símbolo de status, negando-se a tradição colonial, a mão de obra escrava e o modo de vida caipira representado pelo campo.

\section{0 urbanismo fin du siècle paulista e a eletricidade (1890 a 1930)}

O urbanismo paulista entrou em cena nos meados do séc. XIX, através da ferrovia e dos melhoramentos urbanos. Estava ligado à ideia de melhoria das condições de vida associada às inovações propiciadas 
pela Revolução Industrial, aos preceitos higienistas e aos modelos urbanos transportados da Inglaterra e da França para os nascentes núcleos urbanos paulistas.

O modelo retilíneo era a imagem da cidade "civilizada"; assim, as cidades paulistas foram criadas, em sua maioria, como sendo a expressão da "modernidade", em contraposição às antigas cidades coloniais. Sua configuração mudava conforme a disponibilidade de "melhorias", sendo que muitas delas eram movidas a eletricidade. As nascentes indústrias também iam ocupando o espaço entre a ferrovia e a energia, criando novos bairros e centralidades.

Estas "melhorias" ocorreram por todo interior paulista quase que ao mesmo tempo. E, no entanto, como nota De Lorenzo (1993), a realização dessas mudanças aparece, quase sempre, associada à presença de energia elétrica nesses municípios.

A cidade foi se tornando europeia, o seu uso público exigia a assimilação de modos de vida franceses e ingleses; a burguesia cafeeira vivia à "francesa", imitando os padrões de comportamento e de morar europeus, enquanto a classe trabalhadora ainda vivia de forma colonial, mas tinha que se adequar às vilas operárias e aos padrões civilizatórios impostos pela nova cidade que surgia.

As cidades paulistas se tornaram extensas rapidamente. A abertura de novos bairros e subúrbios se deu muito mais pelo preço da terra e pela disponibilidade de transporte (o transporte público permitiu isso) do que pela necessidade de novos locais para moradia. De forma geral, as cidades das Américas são extensas.

Os imigrantes fizeram com que a cidade se transformasse e que surgissem novos comércios e serviços, expandindo a economia. Os novos materiais de construção trazidos pelas ferrovias deram início ao ecletismo.

O modo de vida urbano buscou sobrepor-se ao modo de vida provinciano, característico da sociedade anterior, e foi considerado como nova forma de distinção ou de aristocratização (HOMEM, 1996. p. 60).

O cientificismo era a ordem e o progresso era expresso em números e tecnologia. Os engenheiros e os médicos representavam o novo prestígio da classe dominante. As cidades eram remodeladas segundo a técnica para que se tornassem salubres - engenharia e medicina unidas pela métrica.

As indústrias tinham necessidade de geração de energia, a vida doméstica também se aprimorava com o surgimento de várias máquinas domésticas. A eletrificação era uma necessidade. A geração de energia em grande escala tornava-se imprescindível.

As ferrovias eram os grandes indutores de expansão interior adentro. A tecnologia e o desenvolvimento vieram com e pelas ferrovias. 0 comércio se estabeleceu e a pequena produção industrial tomou fôlego com a maior facilidade de escoamento da produção. Toda a região foi palco de um grande crescimento cultural e tecnológico.

A implantação da estação ferroviária gerava um ponto de atração na cidade. Surgiam ao seu redor hotéis, pensões, barracões de armazenagem, fábricas, bairros dos funcionários da companhia e, invariavelmente um bem cuidado jardim público, como cartão de apresentação aos viajantes. Apareceram, ao seu lado, também as primeiras iniciativas de integração dos transportes, com pontos de carros de aluguel (charretes em sua maioria) e linhas de bondes, mesmo que ainda de tração animal.

A maioria dos municípios paulistas já contava com alguma forma de iluminação pública, a gás ou querosene. Em 1900, já 16 municípios desfrutavam de eletricidade, mais a Capital.

Os dados extraídos dos Anuários (ver Tabela 1), quando comparados com os levantados, deixam o painel incompleto, pois além de faltarem números, misturam-se hidrelétricas com termelétricas. Vê-se ainda, um crescimento da população onde havia energia elétrica, reafirmando a tese de que essa era fator de expansão e modernização. 
Tabela 1. Municípios com iluminação elétrica x região x tempo

\begin{tabular}{|l|l|l|l|l|l|}
\hline Regiões & 1886 & 1900 & 1914 & 1920 & 1934 \\
\hline Capital & 02 & 01 & 05 & 06 & 06 \\
\hline Vale do Paraíba & 01 & 04 & 18 & 22 & 22 \\
\hline Central & & 02 & 24 & 33 & 33 \\
\hline Mogiana & & 04 & 25 & 28 & 28 \\
\hline Paulista & & 04 & 18 & 20 & 20 \\
\hline Araraquarense & & & 18 & 22 & 22 \\
\hline Noroeste & & & 01 & 06 & 16 \\
\hline Alta Sorocabana & 01 & 01 & 13 & 16 & 21 \\
\hline Baixa Sorocabana & & & 07 & 11 & 11 \\
\hline Litoral & & & 02 & 04 & 05 \\
\hline Total & 04 & 16 & 131 & 168 & 184 \\
\hline
\end{tabular}

Fonte: Anuário Estatístico do Estado de São Paulo, de 1901 a 1934. Fundação SEADE.

0 processo de modernização urbana é cheio de assimetrias entre os que dispõem dos serviços urbanos e os que não dispõem, acentuando as diferenças entre pessoas e cidades ricas e pobres, entre zonas urbanizadas e zonas rurais.

De qualquer modo, o processo de urbanização do Brasil, representado aqui pelo estado de São Paulo, teve suas peculiaridades e não foi a simples transposição do modelo importado europeu.

\section{A tipologia de hidrelétricas}

A cidade eclética tem como forte característica a indústria, o urbanismo funcional das quadras regulares, os espaços higienicamente limpos e controláveis, como preconizava Taylor para o sistema de produção. Assim, as cidades paulistas que surgem na esteira da ferrovia são organizadas na distribuição dos seus espaços e providas de benefícios que só poderiam existir na urbanidade, diferente do espaço rural.

Em certa medida, esses mesmos benefícios impunham o desenho da cidade e padrões de construção dos edifícios, como por exemplo, as redes de energia, água, esgoto, telefonia, exigiam uma linearidade do traçado; as indústrias nascentes necessitavam de grandes construções com altos pés-direitos.

Essas exigências criaram padrões identificáveis e tornou possível classificar e datar as cidades por um conjunto de características semelhantes, muito útil a este estudo e aqui utilizado como metodologia.

Não se trata de tipologia, como nas definições de Quatremère de Quincy ou Durand (apud MORTATI; ARGOLLO FERRÃO, 2009b), mas de uma maneira de compreender o evento da eletrificação no Brasil através da identificação dos padrões que a industrialização e, neste caso, a eletrificação, causou na cidade e no modo de vida moderno, refletindo o descolamento do modelo rural e colonial e início ao Brasil moderno e urbano.

As primeiras hidrelétricas formam um conjunto homogêneo do ponto de vista da arquitetura, espalhadas pelo interior do estado de São Paulo. São pequenas edificações, muito simples. A planta é sempre igual: um galpão retangular, sem divisórias ou com uma divisa e mais tarde, um mezanino para manutenção das máquinas. Janelas grandes dispostas de forma simétrica e telha vã. 0 canal de fuga sob a edificação e a câmara de carga mais ao alto. Nem sempre o conduto 
forçado ainda está presente, muitas vezes, por ser de ferro fundido, foi removido quando a usina não mais gerava.

A arquitetura das usinas hidrelétricas é bem mais que o galpão da casa de máquinas. É também o rio, os condutos, as represas, a subestação, as linhas de transmissão e a paisagem (MORTATI, 2013).

No Brasil, a primeira hidrelétrica foi instalada em 5 de setembro de 1889 na cidade de Juiz de Fora, estado de Minas Gerais. Logo depois é instalada na cidade de São Carlos, no estado de São Paulo, a segunda mais antiga hidrelétrica do país: Usina Hidrelétrica de Monjolinho, em 2 de junho de 1893. As dificuldades de geração e transmissão fizeram com que surgissem por todo o interior do estado de São Paulo várias pequenas usinas em vez de grandes centrais, e nas cidades, bairros industriais ou de operários ao longo da linha de transmissão. Outra característica da época era a inexistência de um mercado consumidor consistente, o que levou a um esforço por parte das companhias de eletricidade para divulgar a tecnologia e incentivar o consumo de energia elétrica. Há relatos das invariáveis falências dessas companhias, apesar dos esforços municipais, com várias revisões de contrato para mantê-las em funcionamento.

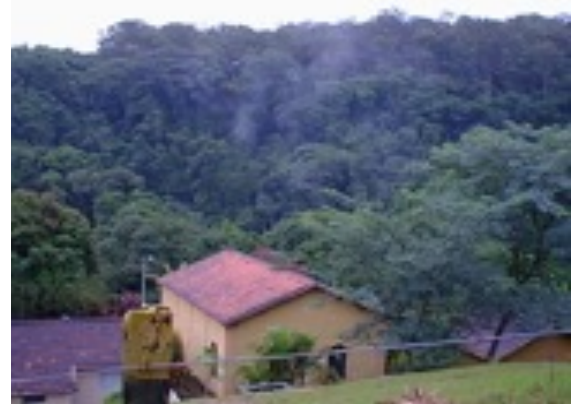

Figura 1. Central de Monjolinho construída em 1893, em São Carlos [SP] Brasil. Edificação típica das primeiras centrais hidrelétricas; assemelha-se muito as tulhas ou paióis rurais. Foto: Débora Nogueira Mortati, 2002.

O conjunto de cidades que empreenderam suas próprias usinas hidrelétricas não compunha qualquer estratégia governamental ou de ocupação do território; todavia, ao se sobrepor a localização das primeiras hidrelétricas à das primeiras ferrovias do estado, pode-se reconhecer uma sequência de implantação, primeiro da ferrovia, seguida pela usina hidrelétrica.

Tal fato deixa claro que o transporte era fator preponderante de desenvolvimento do território e o capital cafeeiro concentrava-se ao longo das linhas da estrada de ferro. Dessa forma as usinas hidrelétricas podem ser compreendidas como benfeitorias secundárias à ferrovia. Era preciso que as cidades já tivessem um determinado nível de progresso e melhorias para suportar a eletrificação.

\section{A influência das usinas hidrelétricas na expansão do território de 4 importantes cidades do interior paulista}

A existência de uma usina hidrelétrica exercia papel de destaque no ordenamento do território de qualquer município, quer como expressão de modernidade e poderio, quer como fator relevante na criação de novas indústrias. A implantação das hidrelétricas deveria obedecer a outras condicionantes que não só os caminhos (estradas ou ferrovias) mas também a proximidade da fonte geradora de energia, já que as perdas eram grandes e o custo da rede era muito alto no início do processo.

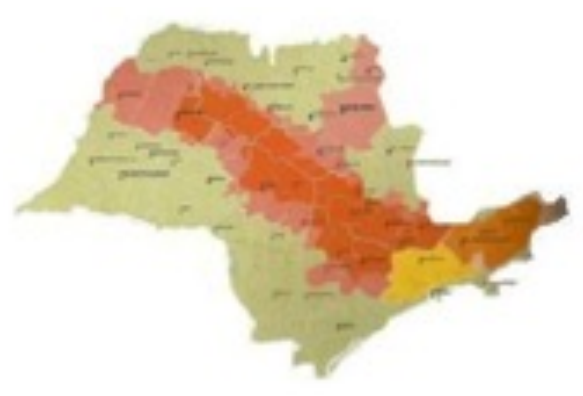

Figura 2. Indicação dos eixos de industrialização no interior paulista. Fonte: MARANHÃO, 2002. p. 68.

O avanço da urbanização, com o consequente aumento da demanda por serviços públicos, e o incremento das atividades industriais, observadas no sudeste do país, abriram boas perspectivas para investimento no incipiente campo da energia elétrica (CENTRO DA MEMÓRIA DA ELETRICIDADE NO BRASIL, 1988. p.28).

A geração de energia elétrica no Brasil vai desenhando novas fronteiras entre o rural e o urbano, o campo e a indústria.

Tendo em vista o ordenamento do território das principais cidades do interior paulista, a condição ideal para a implantação de uma nova indústria era estabelecida pelo seu posicionamento no quadrante delimitado pela ferrovia (de acordo com o sítio da estação ferroviária) e da rede elétrica 
(de acordo com o sítio da usina). Assim, a indústria conseguiria mais facilmente receber matériaprima e escoar sua produção, abastecida pela energia hidrelétrica - uma fonte constante (mas não muito confiável), independente de horários e operários que garantissem o abastecimento.

Uma consequência direta sobre o desenvolvimento e a ordenação do território das cidades paulistas que implantaram usinas hidrelétricas entre 1890 e 1930 é o surgimento de bairros no quadrante da estação com a usina.

As Figuras 3 e 4 foram elaboradas usando-se a base do Google Mapas (https://maps.google.com.br/ maps). No cruzamento dos eixos está o centro reconhecido como o local onde a cidade surgiu; normalmente uma igreja e a praça central. Em preto foi realçado o traçado da ferrovia e um pin marca a localização da estação ferroviária. Outro pin demarca a posição da usina hidrelétrica histórica. Desta forma, delimitou-se o "quadrante da estação ferroviária/central hidrelétrica".
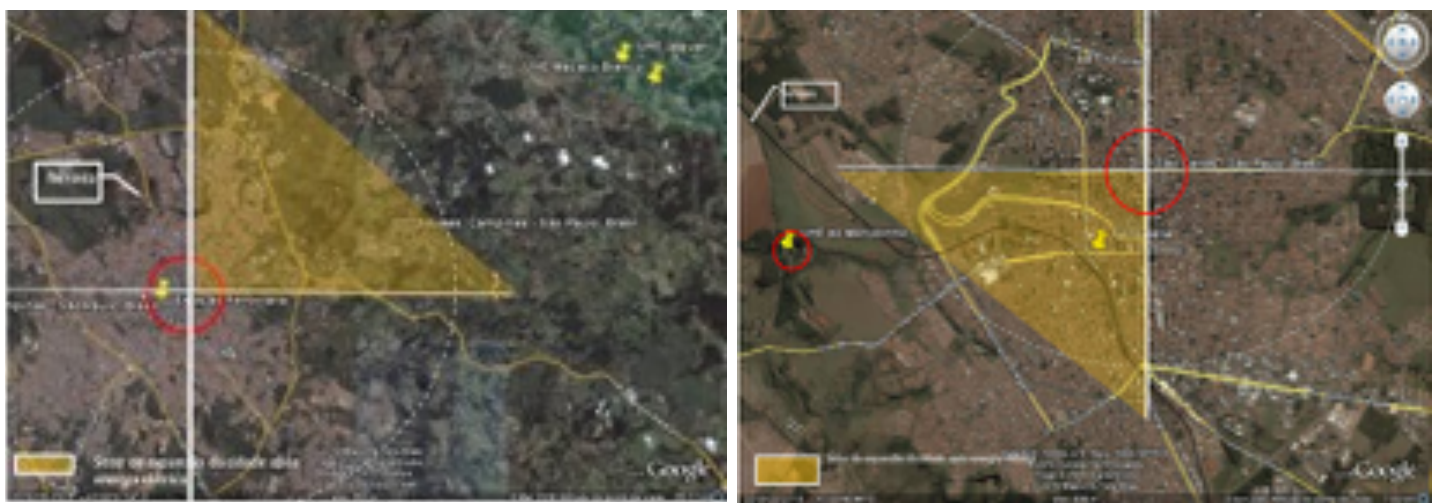

Figura 3. À esquerda, Setor da cidade de São Carlos, e à direita Setor da cidade de Campinas. Elaboração própria, a partir da base do Google Mapas <https://maps.google.com.br/maps>.
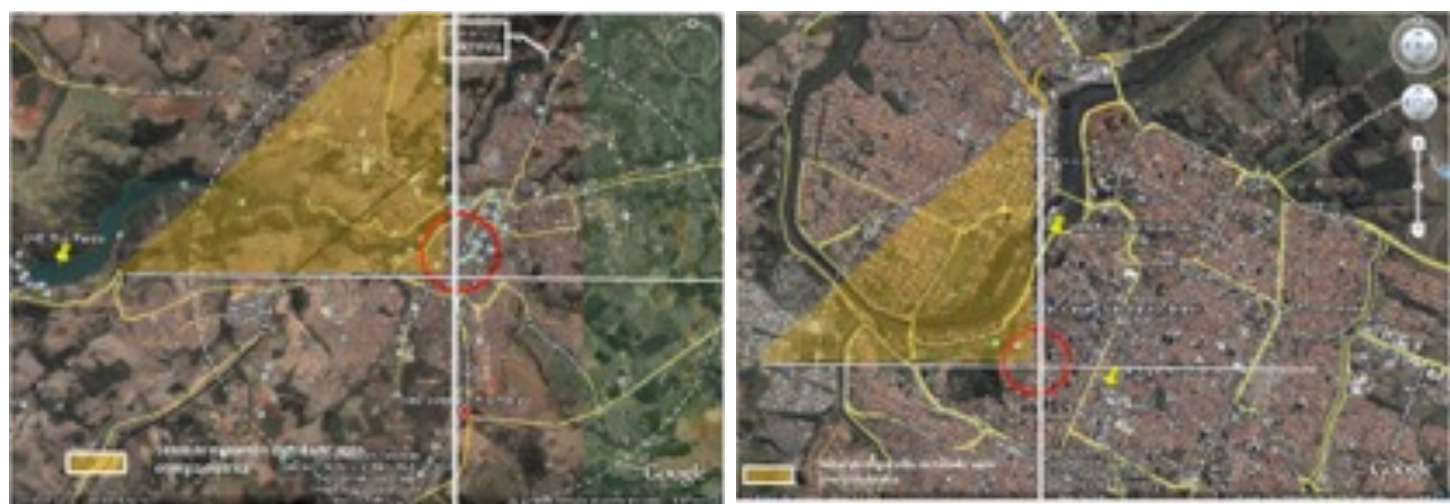

Figura 4. À esquerda, Setor da cidade de Piracicaba, e à direita Setor da cidade de São José do Rio Pardo. Elaboração própria a partir da base do Google Mapas <https://maps.google.com.br/maps>.

Nota-se nas quatro cidades o surgimento no "quadrante estação ferroviária/central hidrelétrica" (setores hachurados em amarelo nas Figuras 3 e 4 ) dos primeiros bairros operários e das primeiras fábricas, numa expansão da cidade justificada pela disponibilidade de energia para as indústrias e proximidade da estrutura para o escoamento da produção. Não é exatamente a posição da casa de força das usinas o que mais interessa, mas o percurso da linha de transmissão até a cidade.

Ao longo das linhas de transmissão surgiram fábricas e bairros. O desenvolvimento da cidade no "quadrante energia/ferrovia" não é uma regra no interior paulista, mas é preponderante. Quase todas as cidades paulistas por onde passa a ferrovia possuem uma central hidrelétrica; e o "quadrante central hidrelétrica/estação ferroviária" constituía um novo vetor de crescimento, segregado do centro tradicional, onde se localizariam as indústrias e os imigrantes.

Era de se esperar, portanto, que os bairros operários ou mesmo o setor de serviços fossem se

NOGUEIRA, D.M.A.; ARGOLLO FERRÃO, A.M. Hidrelétricas no desenvolvimento urbano e territorial de São Paulo.

Labor \& Engenho, Campinas [SP] Brasil, v.9, n.1, p.19-36, jản./mar. 2015. Disponível em: www.conpadre.org 
posicionando nas imediações das indústrias, onde havia também disponibilidade de terra barata, uma vez que ainda não fazia parte da cidade. Muitas vezes eram as próprias indústrias que criavam os bairros para seus operários. Surgem os "subúrbios" ou os "bairros", identificados, no começo do século XX, com indústria e imigração.

Conforme De Lorenzo (1993) as cidades que mais se destacaram quanto ao desenvolvimento da indústria foram as que dispunham de eletrificação. As maiores cidades também dispunham das maiores potências.

A eletrificação priorizou os centros das cidades, quase nunca aparecendo nos novos bairros operários. A linha de transmissão quase sempre passava por sobre suas cabeças sem permitir que pudessem desfrutar das comodidades da energia elétrica.

Claramente é um indicador de que a energia elétrica além de cara não era amplamente disponível. 0 antigo e o moderno ainda conviveriam por longos anos nas cidades e ser operário (uma condição moderna) não implicava em ter um cotidiano equivalente. Vivia-se a contradição de terem os trabalhadores nas cidades uma função moderna e urbana, morando e agindo em condições compatíveis com o modo de vida rural, enquanto a elite que vivia do mundo rural, morava na cidade moderna e usufruía dos novos confortos urbanos.

As companhias de eletricidade eram também, em sua maioria, proprietárias das companhias de bondes. Incentivavam o consumo da energia através de parques de diversões, carrosséis, pistas de patinação, bailes e agremiações ou mesmo nos footings das praças iluminadas; tudo patrocinado pelas companhias de energia.

Outra utilização do patrimônio das companhias de energia foi o de loteamento das terras valorizadas pelo lazer nas margens dos rios e represas.

A energia elétrica está intrinsecamente ligada a esses processos. Além de ter participado do processo de crescimento urbano como infraestrutura, a eletrificação pode ser considerada, também, um elemento explicativo desse processo, especialmente da concentração e diferenciação urbanas (DE LORENZO, 1993).

Na década de 1930 a atividade industrial torna-se o principal fator de crescimento urbano e da geração de energia. Também a disponibilidade de energia elétrica é um elemento de qualificação e diferenciação das cidades em relação às zonas rurais ou às zonas menos valorizadas das próprias cidades. Pode-se dizer que a partir deste período o estado de São Paulo está eletrificado e o modo de vida moderno, urbano e industrial praticamente consolidado como modelo almejado.

Também na década de 1930 firmam-se e popularizam-se o consumo de novos produtos, tipicamente urbanos, como rádios, ventiladores, cinematográficos, equipamentos médicose cirúrgicos (especialmente, o raio X), etc., que dependiam da energia elétrica como insumo (DE LORENZO, 1993).

O ordenamento do território paulista com a implantação da eletricidade, suas usinas e companhias concessionárias, pode ser compreendido a partir dos Mapas apresentados nas Figuras 5 a 13.

Há que se notar que a divisão territorial dos municípios paulistas é diferente em cada período (ver Figuras 5 a 13), pois evolui de acordo com os sucessivos desmembramentos e criação de novos municípios. Os territórios municipais eram em média muito maiores assim como o número de municípios existentes era menor. Com o passar do tempo e as inevitáveis mudanças na economia e na política, os territórios municipais vão se fragmentando. Tal fato levou a uma distorção visual entre os dados e os mapas apresentados nas Figuras 5 a 13, de forma que - por exemplo, de 1914 para 1929 a porcentagem de municípios eletrificados diminuiu (ver Tabela 2), embora a mancha de ocupação do território paulista pela energia elétrica tivesse aumentado, pois havia mais municípios eletrificados.

Durante os primeiros 30 anos do século XX nota-se uma grande fragmentação do território devido a sucessivos desmembramentos e criação de municípios, principalmente na primeira década. 
Tabela 2. Municípios do estado de São Paulo com iluminação elétrica (1886-1940).

\begin{tabular}{|c|c|c|c|}
\hline Data & № de municípios em SP & № de municípios com energia elétrica em SP & porcentagem \\
\hline 1886 & 126 & 04 & $3,17 \%$ \\
\hline 1900 & 174 & 16 & $9,19 \%$ \\
\hline 1914 & 185 & 131 & $70,81 \%$ \\
\hline 1929 & 259 & 168 & $64,86 \%$ \\
\hline 1940 & 270 & 184 & $68,15 \%$ \\
\hline
\end{tabular}

Fonte: Anuário Estatístico do Estado de São Paulo, de 1901 a 1940. Fundação SEADE.

\subsection{Primeira década: $1890-1900$}

Na última década do século XIX o Estado intensificou o controle sanitário na cidade e na moradia. 0 país era visto no exterior como selvagem e infestado de moléstias tropicais. Com uma imagem tão negativa era difícil atrair capital e mão de obra estrangeiros. Medidas sanitárias foram implantadas a todo custo. Há muitos relatos sobre cortiços e "cabeças-de-porco" derrubados, desapropriações para alargamento de ruas e abertura de praças, taxas de pavimentação e de implantação dos serviços de água e esgoto e mudanças impostas para as novas vilas operárias.

Surgem bairros em conformidade com os novos princípios urbanísticos, com denominações que remetiam à nova postura de salubridade e beleza, tais como Água Branca, Água Limpa, Higienópolis, Aclimação, os mais variados Jardins "alguma coisa" [...], e os que remetiam a Paris da Belle Époque reurbanizada por Haussmann, como os vários Champs Ellysées e Boulervards.

Nos novos bairros, as novas construções residenciais se tornavam independentes, isolando-se no lote. Esta nova implantação, além de ser uma medida sanitária exigida pelos Códigos de Obras, era também símbolo de status e modernidade.

Surgiram também os porões de ventilação, obrigados pelo Código de Higiene de 1894, para evitar a umidade. A legislação de 1886 estipulou a abertura de ruas mais largas e fixou a altura do pé-direito da casa térrea em cinco metros; procurou disciplinar a construção de cortiços. Já o Código de Higiene de 1873 direcionou as casas de saúde para as partes mais altas e salubres da cidade, proibiu o lançamento de esgotos nas ruas e pretendeu combater a poluição das águas e do ar, mediante a arborização das várzeas e preservação das matas próximas.

Com o Encilhamento, na última década do século XX, e a grande desvalorização do café vários fazendeiros passaram a apostar em novas economias como forma de fugir da inflação.

Apesar das dificuldades econômicas e políticas, os empréstimos internacionais recomeçaram a afluir de forma mais intensa. Sanearam-se os déficits internos e as contas externas, e o país passou a progredir materialmente. Equiparam-se os seus portos, ampliou-se a rede ferroviária, instalaram-se as primeiras usinas de energia elétrica e modernizaram-se as suas principais cidades (HOMEM, 1996. p. 115).

Enquanto o fazendeiro ocupava os cargos políticos e de industrial, os imigrantes ocupavam uma faixa intermediária, de assalariados a negociantes ou emergentes industriais.

Uma vez na cidade, os imigrantes buscavam de preferência, a periferia, onde nascia a pequena propriedade rural, abastecedora da população, ao lado de tecelagens, da indústria extrativa e de alimentos como massas, óleos e chocolates. [...] Ao lado dos empresários de café, começavam a despontar os industriais estrangeiros (HOMEM, 1996. p. 117).

No antigo centro, além do comércio varejista, continuavam a existir hotéis, escritórios e repartições públicas. 
O lazer e a vida boêmia também permaneceram no centro; porém a aristocracia se afastou, procurando os novos bairros. As classes populares tomaram conta das moradias e o centro antigo se tornou um problema para a cidade aristocrática.

Por outro lado, o Estado estimulou o fracionamento da terra, dando impulso à especulação imobiliária e estabelecendo normas de loteamento, que passaram a variar conforme o tipo de usuário e a localização.

Nas áreas mais baixas e úmidas, portanto mais baratas ou mesmo no entorno das ferrovias, acabaram se desenvolvendo bairros operários. Nos terrenos mais altos e secos surgiram boulevards, bairros nobres e arborizados, como a Avenida Paulista, na capital do estado.

Totalmente programados para receber as camadas urbanas mais abastadas, aqueles loteamentos eram servidos por bondes a tração animal e contavam com rede de água, esgotos e luz (HOMEM, 1996. p. 123).

0 aumento demográfico nas cidades levou à febre de construções e assim mesmo faltavam moradias. A população paulista, entre 1886 e 1900, cresceu de 1.221 .380 para 2.279.608 habitantes. Em 1886 havia 126 municípios e em 1900, 174 no estado.

Ao se correlacionar o aumento de população e o crescimento das cidades com disponibilidade de energia elétrica neste período não se obtém dados conclusivos pois na mesma época ocorre uma grande epidemia de febre amarela dizimando a população de algumas das principais cidades já eletrificadas, como Campinas; consequentemente, a migração para cidades menos infectadas foi grande no estado, refletindo portanto, nos dados de 1900, uma tendência de volta para as cidades de origem.

Nestes primeiros anos de implantação da energia elétrica em São Paulo não se observa um expressivo aumento da população nas cidades eletrificadas. Na média, o crescimento populacional é o mesmo de outras cidades do oeste paulista que não dispunham do benefício.

Tabela 3. Acréscimo de população em alguns municípios do estado de São Paulo e disponibilidade de energia hidrelétrica.

\begin{tabular}{|c|c|c|}
\hline Cidade & $\begin{array}{c}\text { Aumento da população } \\
\text { entre 1886 e 1900 (\%) }\end{array}$ & $\begin{array}{c}\text { Disponibilidade de } \\
\text { energia hidrelétrica }\end{array}$ \\
\hline São Paulo & $402,80 \%$ & Não \\
\hline Santos & $222,90 \%$ & Não \\
\hline Campinas & $218,50 \%$ & Não \\
\hline Rio Claro & $58,4 \%$ & Sim \\
\hline Piracicaba & $14,55 \%$ & Sim \\
\hline Ribeirão Preto & $558,0 \%$ & Sim \\
\hline Jaú & $82,70 \%$ & Não \\
\hline Franca & $54,29 \%$ & Não \\
\hline Casa Branca & $108,20 \%$ & Não \\
\hline
\end{tabular}

Fonte: Anuário Estatístico do Estado de São Paulo, de 1901 a 1940. Fundação SEADE.

No final do século XIX, de 1883 a 1899, são criadas vinte e três usinas (entre térmicas e hidrelétricas) no Brasil. Dentre essas, onze hidrelétricas em São Paulo sendo dez na região centro-oeste do estado; enquanto as capitais, São Paulo e Rio de Janeiro, continuavam a ser iluminadas por lampiões de gás.

Estas usinas hidrelétricas pioneiras eram quase experimentais. Suas histórias refletem dificuldades de implantação com problemas alfandegários, falta de mão de obra qualificada para a montagem, 
falta de uma arquitetura apropriada, dificuldade de se estabelecerem as linhas de transmissão, falta de equipamentos e a dificuldade de importação, além dos relatos de problemas de funcionamento como os incêndios, alagamento das instalações e acidentes de trabalho.

Haviam no estado de São Paulo dez empresas de energia (Figura 5), cada uma com sua própria usina, exceto a de Ribeirão Preto que montou duas pequenas hidrelétricas num período de quatro anos.

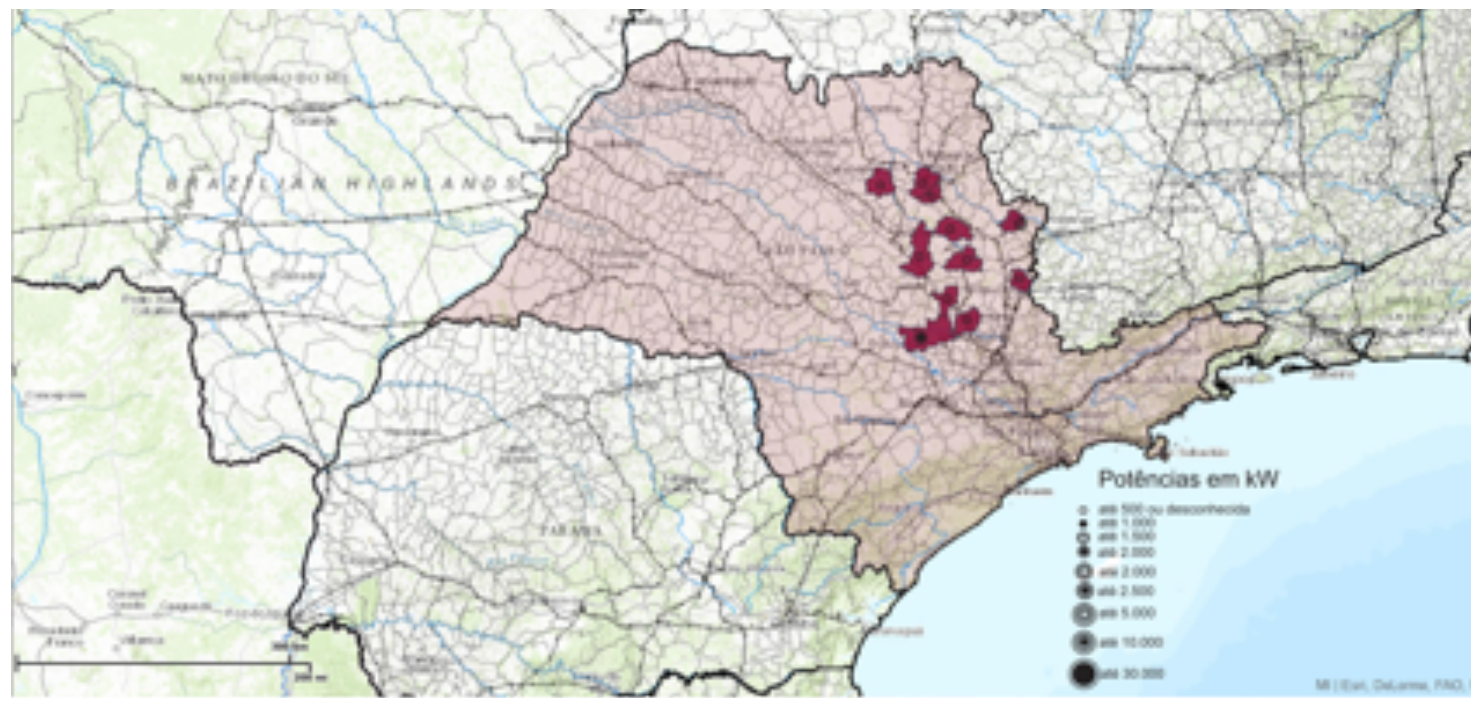

Figura 5. Municípios de São Paulo com usinas hidrelétricas e a Potência das respectivas centrais com a qual começaram a operar no estado (1890-1900). Elaboração própria utilizando a Plataforma ODR, 2014.

De 1890 a 1900 a eletrificação urbana dependeu quase que exclusivamente da expansão do espaço direcionado pela economia cafeeira.

A escolha das cidades onde se criariam usinas hidrelétricas não fazia parte de qualquer estratégia de ocupação do território. Todavia, ao se sobrepor a localização das primeiras hidrelétricas à das primeiras ferrovias do estado, observa-se uma coincidência que revela em sequência a implantação da ferrovia e da usina hidrelétrica em seguida (Figura 6).

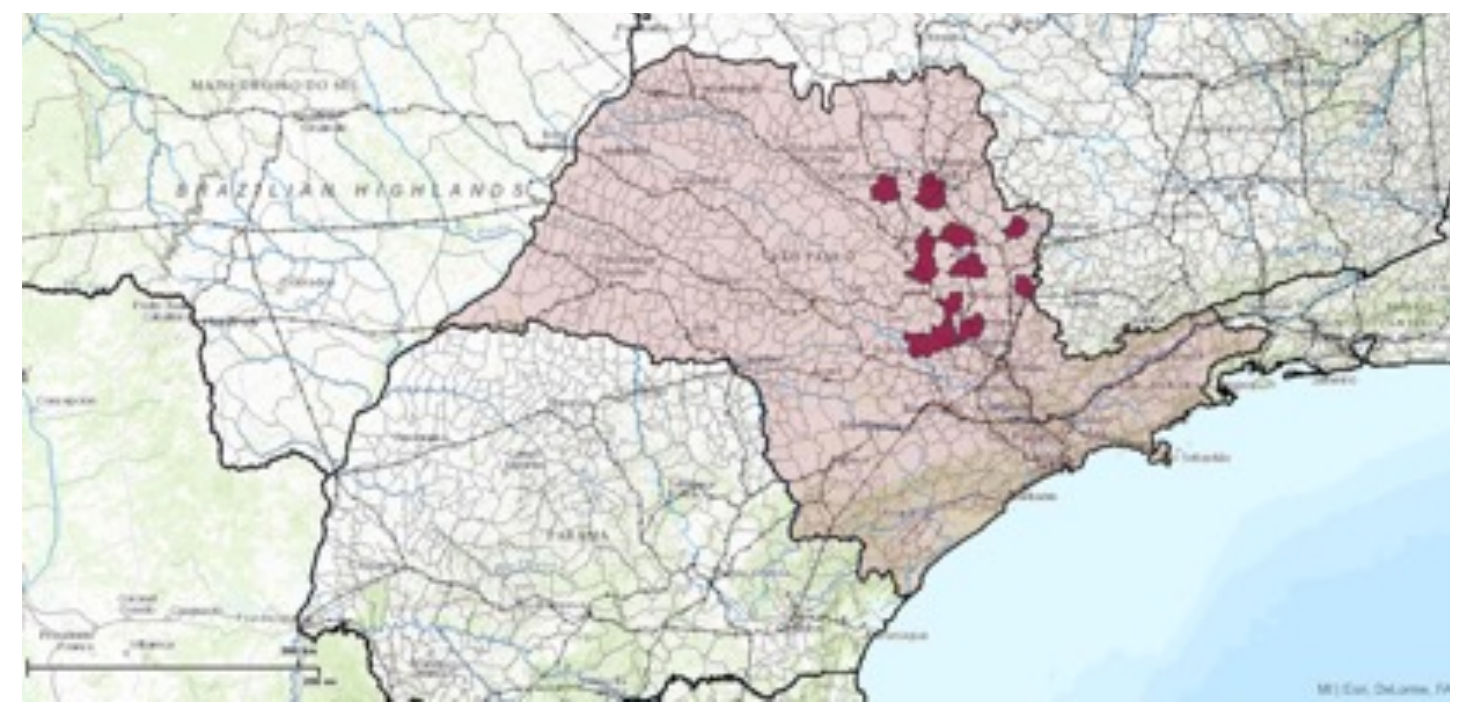

Figura 6. Localização das centrais hidrelétricas que surgiram de 1890 a 1900 no estado de São Paulo sobreposta à localização das ferrovias então existentes. Elaboração própria utilizando a Plataforma ODR, 2014.

A ferrovia era preponderante para o desenvolvimento territorial e o capital cafeeiro concentrava-se ao longo das estradas de ferro. As usinas hidrelétricas são benfeitorias secundárias à ferrovia. 


\subsection{Segunda década: 1901-1910}

Em 1907 São Paulo já participava com 16\% de toda a produção industrial do país, valor que passou para 31\% em 1919 e 41\% em 1939 (NEGRI; GONÇALVES; CANO, 1988). Já no fim da década anterior, em 1900, 6,32\% dos municípios paulistas eram dotados de iluminação pública. Em 1915 correspondiam a $68,1 \%$ do estado - 126 dos 185 municípios.

Observa-se certo adensamento na região metropolitana de São Paulo, difundindo-se a tecnologia nas cidades mais equipadas e abastadas da época. 0 número de empresas e usinas também aumenta em relação à década passada.

Ainda há muitos relatos de falências, acidentes de trabalho e receio quanto ao uso da eletricidade. As indústrias se desenvolviam junto aos trilhos das ferrovias, sobretudo a de bens de consumo. 0 resto continuava a ser importado.

Os bairros elegantes eram muito diferentes das zonas operárias que, em sua maioria não tinham ruas calçadas nem iluminação; "a falta de saneamento básico deixava-as mais vulneráveis às enchentes e à proliferação dos focos de moléstias transmissíveis" (HOMEM, 1996. p. 193). A classe média se expandia associada ao desenvolvimento do comércio e da indústria; era constituída também por funcionários públicos, militares, professores e profissionais liberais.

Em 1905 foram reformados o Jardim da Luz, a Praça da República e o Largo Paissandu. Melhoraram o Viaduto do Chá e alguns largos centrais, plantando-se 25.692 árvores nas praças e nas ruas da cidade de São Paulo.

Logo após iniciaram-se os serviços de bondes elétricos na capital, com as linhas preferencialmente irradiando-se do centro em direção às antigas saídas da cidade. "De modo geral, a urbanização incidiria nos trajetos dos bondes elétricos [...]" (HOMEM, 1996. p. 197).

As cidades do interior também promoveram grandes transformações como as principais cidades do país. Surge, em 1901, a primeira grande - para a época - usina hidrelétrica, projetada para abastecer várias cidades mais a capital: a UHE Parnaíba, da Light.

A questão do prestígio político também é uma constante nos relatos sobre a implantação da energia elétrica. Observa-se tal aspecto nas palavras um político da cidade de Salto [SP], proferidas durante o ato de inauguração da iluminação pública daquela cidade que, segundo ele, se beneficiaria de um melhoramento a muito esperado e assim faria "boa figura no confronto com as outras urbes do estado que já estavam usando esse sistema de iluminação".

Surgem nesta década mais 34 usinas hidrelétricas (ver Figura 7). A potência aumentou de 1580 HP para 13.150 HP, conforme De Lorenzo (1987).

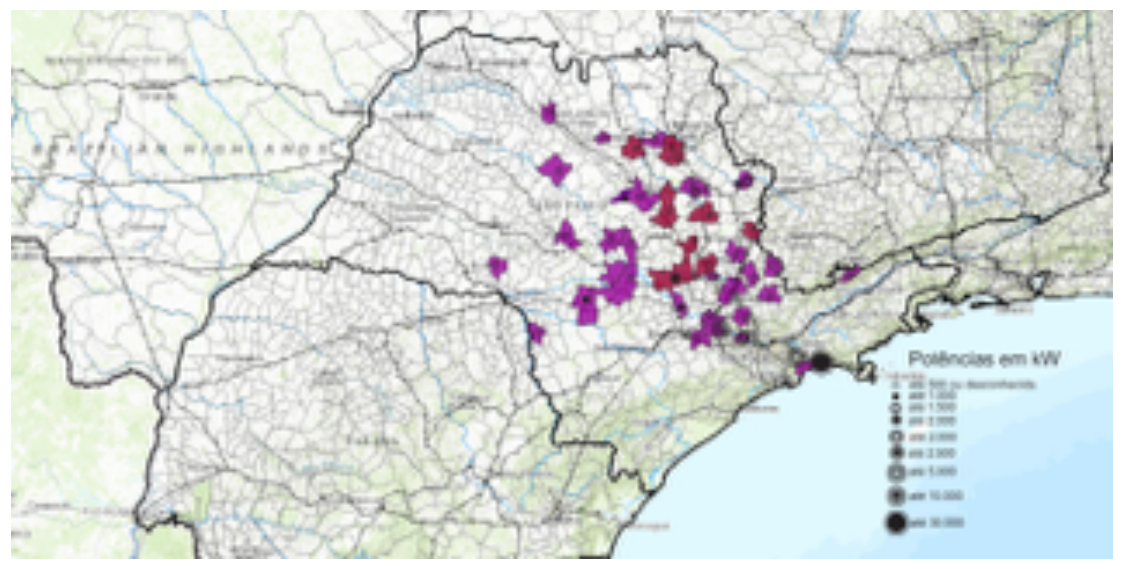

Figura 7. Municípios de São Paulo com usinas hidrelétricas e a Potência das respectivas centrais com a qual começaram a operar no estado (1901-1910). Elaboração própria utilizando a Plataforma ODR, 2014. 


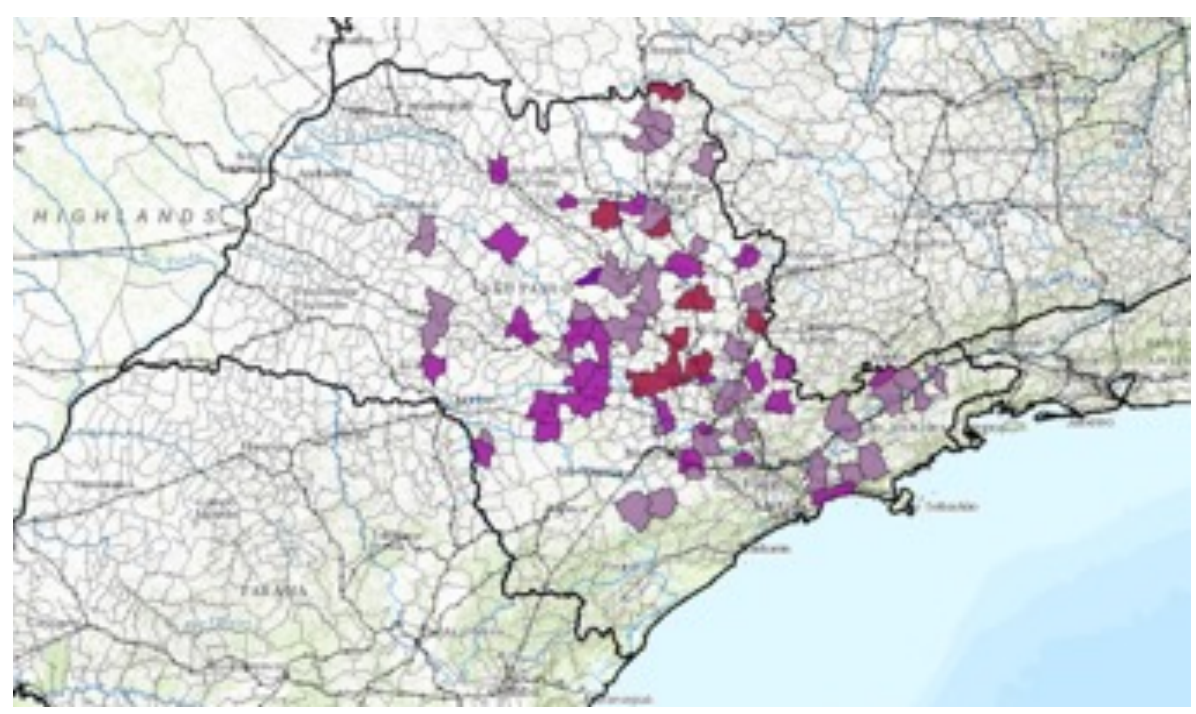

Figura 8. Localização das centrais hidrelétricas que surgiram de 1890 a 1910 no estado de São Paulo sobreposta à localização das ferrovias então existentes. Elaboração própria utilizando a Plataforma ODR, 2014.

Como os municípios ainda não haviam se fragmentado muito no centro-oeste do estado, a mancha formada pelas cidades acesas representa quase metade do território paulista. Eram somente 46 cidades iluminadas e não havia iluminação na zona rural. Então a mancha é exagerada e tende a parecer menor nas próximas décadas conforme o número de cidades vai aumentado. A iluminação avança para o oeste e se adensa em torno da capital.

Até 1879 a Província de São Paulo viu criarem-se 100 municípios e nos últimos vinte anos do século criaram-se mais 61, entrando São Paulo no século XX com 161 municípios. Na primeira década do século, marcada pela crise cafeeira, nenhum novo município foi criado, mas nos anos 10 a retomada da expansão cafeeira levou à criação de mais de 31 municípios e, na década seguinte, quando o Governo Provincial assumiu diretamente a política de sustentação do café, houve uma febre expansionista na frente pioneira, em que mais 53 municípios foram criados. Assim, São Paulo entrou na crise de 29 com uma rede urbana constituída por 245 municípios criados, quase a metade do número atual. (NEGRI, GONÇALVES E CANO, 1988).

Na década de 1920 há uma verdadeira euforia no movimento de implantação de usinas hidrelétricas no estado de São Paulo. É um momento de expansão das companhias, quando as mais estruturadas implantam uma segunda usina, trocam o maquinário por mais potentes e formam pequenas redes de fornecimento, já não mais restritas a uma cidade. Ainda há muitos relatos de falências, acidentes e receio quanto ao uso da eletricidade.

\subsection{Terceira década: $1911-1920$}

Na terceira década o número aumenta para 76 usinas hidrelétricas. A potência aumentou $1500 \%$ de 4040 HP para 59745 HP, sendo que a Light era responsável por 45,4\% da produção de energia.

Há uma euforia da implantação de hidrelétricas com forte interiorização da geração. É um momento de expansão das companhias. Surgem tentativas de criar um sistema mais integrado de produção e distribuição, portanto as fusões se acentuam.

De Lorenzo (1993) conta um caso muito interessante de como a expansão da eletrificação acontecia e sua importância no desenho da paisagem e como fator de indução urbana:

Na região do Vale do Paranapanema a eletrificação chegou ao final da década de 1910, quando o governo do Estado de São Paulo contratou a Empresa José Giorgi para a 
construção de $400 \mathrm{~km}$ de ferrovia em prolongamento da Estrada de Ferro Sorocabana, até Presidente Epitácio, nas barrancas do Rio Paraná. Neste trabalho, à medida que as picadas iam sendo abertas no então sertão do Oeste Paulista, a empresa construtora substituía os lampiões a gás em seus acampamentos por luz elétrica gerada em locomóveis a vapor e caldeiras a lenha. Quando os trilhos da ferrovia chegaram em Assis, em 1914, foi inaugurada a primeira usina termoelétrica, que além de fornecer luz elétrica àquela área, também acionava cinco serrarias que funcionavam no município (DE LORENZO, 1993).

As vilas que surgiram ao longo das linhas se transformaram em cidades. Faziam parte desse sistema 13 cidades do Vale do Paranapanema.

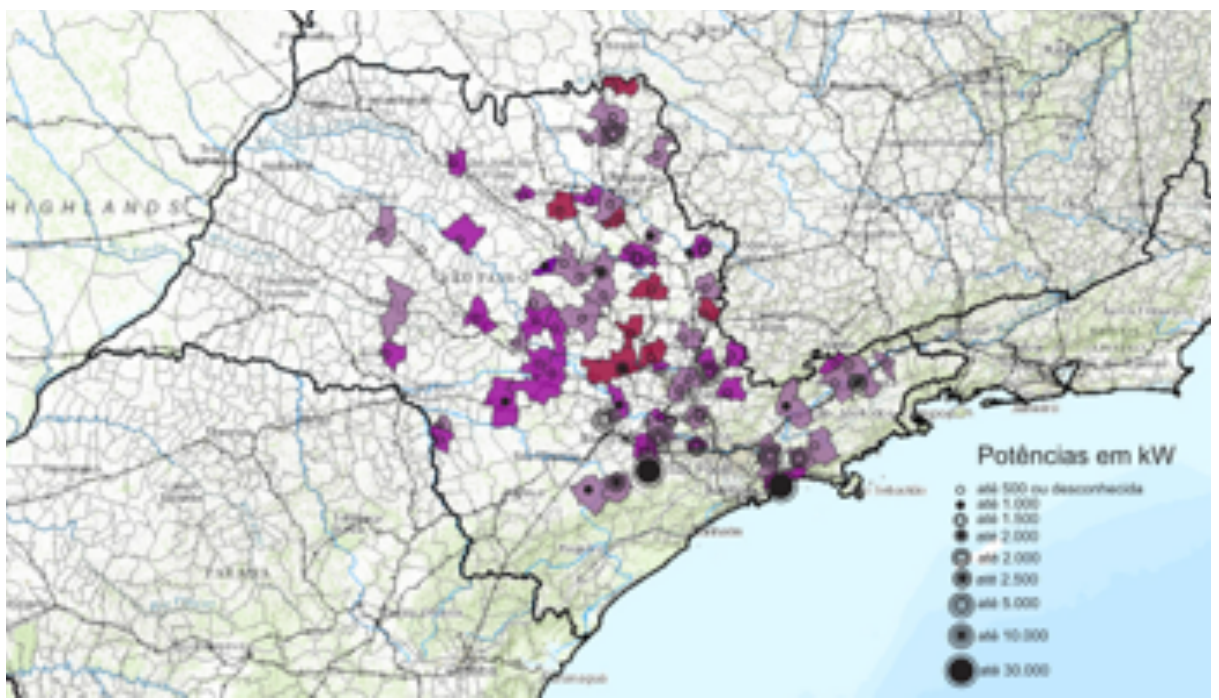

Figura 9. Potência das centrais hidrelétricas com a qual começaram a operar no estado. Fonte: mapa elaborado no ODR, 2014.

Nos anos 10 foi retomada a expansão cafeeira e foram criados 31 municípios, e na década seguinte, mais 53. Assim, São Paulo entra na crise de 29 com 245 municípios.

A região central e da Estrada de Ferro Paulista foram as que mais aumentaram a capacidade de gerar energia elétrica, mais do que dobrando a potência disponível no início da década de 1910. Na região de Ribeirão Preto a energia passa de 40 HP em 1900 para 6000 HP em 1910 e a primeira hidrelétrica da região de Bauru é ligada (UHE São José, em Marília).

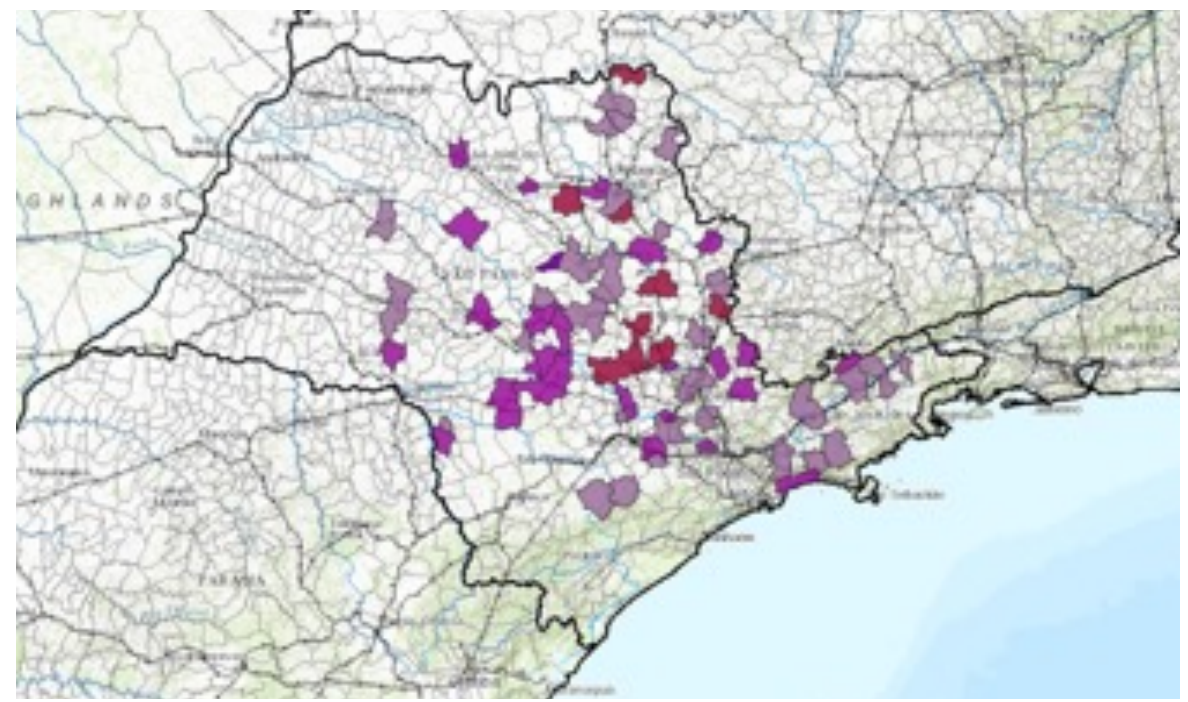

Figura 10. Centrais hidrelétricas que surgiram de 1890 a 1940 no estado sobreposto ao de ferrovias. Fonte: mapa elaborado no ODR, 2014. 
As principais mudanças nesse período se dão na indústria, que se vê obrigada a adotar a energia elétrica por falta ou altos preços do carvão ou óleo. Após a guerra a matriz hidrelétrica já estava consolidada no Brasil.

Em 1914, já eram 70,80\% dos municípios do estado que possuíam iluminação pública - 126 dos 185 municípios.

As cidades já contavam com diversos teatros e os esportes como o futebol, o tênis e a bola ao cesto estavam em moda. Andar de bicicleta também era uma diversão, porém só da elite e principalmente para as mulheres que passeavam pelos bulevares.

Predominavam a euforia, o otimismo, a crença no progresso material e na secularização como portadores da felicidade. A belle époque paulistana estava em pleno vigor. Após a fotografia, o telégrafo e o telefone, chegaram a São Paulo o fonógrafo, o gramofone e o cinema, além do automóvel. Em 1912, havia diversos cinemas no centro [...] (HOMEM, 1996. p. 197).

Nesta nova sociedade tipicamente urbana que surgiu, havia muitas diferenças entre as camadas, havia a elite e a classe baixa, composta em grande parte de imigrantes, mas havia imigrantes ricos também, que formavam uma classe a parte por não serem bem aceitos na sociedade.

Na verdade, havia diversas cidades dentro de São Paulo. Uma, acanhada e pacata, onde predominavam as construções e os transportes tradicionais, com pouco conforto, e se levava vida provinciana. Outra, bastante movimentada e alegre, atada ao centro, onde se concentravam o comércio, a administração pública, o lazer, os jornais, os hotéis, os escritórios, etc. [...]. Uma terceira cidade emergia além ferrovias, de difícil acesso. Dispersa no sentido norte, leste e sul, era ocupada por fábricas, chaminés, casas populares e cortiços, construídos nas terras mais baixas e molhadas das várzeas. Servia de contraponto à cidade rica em franco processo de urbanização, voltada para oeste, composta do centro, Viaduto do Chá, Vale do Anhangabaú, atados aos bairros médios e elegantes. Foi nesta cidade que surgiram os palacetes (HOMEM, 1996. p. 199).

Em 1920 o número de habitantes no estado atinge 4.592.188 (Tabela 4). A população dobrou em 20 anos. Em 1929, apesar da crise, São Paulo tem 245 municípios, quase metade do número atual.

Tabela 4. Estado de São Paulo - Iluminação Elétrica e Distribuição da População e Municípios por Região, 1920.

\begin{tabular}{|c|cccc|}
\hline & № municípios & Municípios ilum. elétrica & População & $\%$ \\
\hline Grande São Paulo & 13 & 4 & 721.143 & 15.7 \\
\hline Litoral & 10 & 2 & 202.535 & 4.4 \\
\hline Vale do Paraíba & 28 & 7 & 398.625 & 8.7 \\
\hline Sorocaba & 40 & 13 & 555.650 & 12.1 \\
\hline Campinas & 19 & 11 & 1034385 & 22.5 \\
\hline Ribeirão Preto & 44 & 16 & 1054302 & 23.0 \\
\hline Bauru & 23 & 7 & 343.541 & 7.5 \\
\hline Oeste Pioneiro & 8 & 8 & 282.005 & 6.1 \\
\hline Total Est. São Paulo & $\mathbf{2 1 5}$ & $\mathbf{6 8}$ & $\mathbf{4 5 9 2 1 8 0}$ & $\mathbf{1 0 0 . 0}$ \\
\hline
\end{tabular}

Fonte: CENSO Demográfico de 1920.

As cidades da década de 20 tinham, em geral, mais de 20 mil habitantes e hidrelétricas com potência instalada superior a 3.000 HP. A demanda por energia a partir daí, ao contrário das duas 
primeiras décadas, quando era prioritariamente para iluminação pública, passa a ser para fornecimento para as residências e indústrias. No final desta década a capacidade de geração de energia total do estado aumentou $176 \%$ passando de $225.499 \mathrm{HP}$ para $398.130 \mathrm{HP}$.

Da Tabela 4, nota-se a grande interiorização da iluminação pública. A maioria das companhias era de serviço local. No oeste paulista várias usinas já surgiram interligadas. Algumas empresas mais antigas também começam a se interligar. As linhas de fornecimento também são ampliadas e interligadas de modo geral.

\subsection{Quarta década: $1921-1930$}

Após a guerra até a crise de 29, a indústria nacional teve um crescimento expressivo, consequentemente o consumo de energia também.

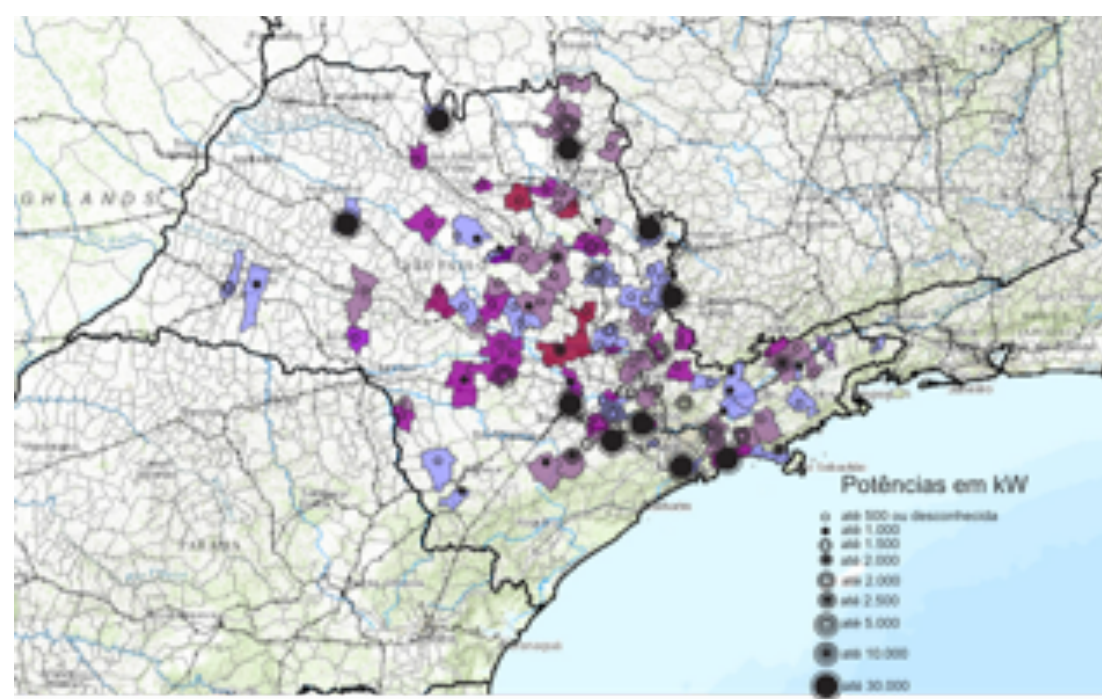

Figura 11. Potência das centrais hidrelétricas com a qual começaram a operar no estado. Fonte: mapa elaborado no ODR, 2014.

Do mapa de 1930 nota-se o movimento de expansão em busca de novos mercados, no interior do estado, em direção ao chamado "café novo". De acordo com De Lorenzo (1993), nessa época a eletrificação atingia aproximadamente $71 \%$ dos municípios.

Em 1920, 128 dos 215 municípios existentes no estado já estavam iluminados. A eletrificação atingia praticamente $75 \%$ do estado. Em 1930, havia 182 municípios com iluminação pública no estado. 0 extremo oeste, desde Rio Preto até Marília, "ocupando uma área correspondente a um terço do território paulista, passou de 282 mil para 1601 mil habitantes" (NEGRI, GONÇALVES E CANO, 1988).

As regiões de Campinas e Ribeirão Preto não tiveram um expressivo aumento da potência instalada. Não há novas usinas nessas regiões nessa época. Mas a potência aumentou de 35.200 HP para 49.311 HP na região de Campinas e de 32.729 HP para 34.988 HP na região de Ribeirão Preto, o que indica que as usinas somente foram aperfeiçoadas, refletindo um avanço tecnológico. Isso ocorreu após 1927, quando a AMFORP adquiriu várias usinas pelo interior do estado, dando início a interligação da rede de distribuição - 0 anel da AMFORP.

A expansão foi bastante intensa também na região do Litoral e do Vale do Paraíba e avançou nas áreas das regiões de São José do Rio Preto e Marília, onde surgiram sete usinas na década de 20. No recenseamento de 1934 a região de Campinas passou de 1034 mil (1920) para 1084 mil, Ribeirão Preto, que tinha 677 mil em 1920, passa para 792 mil, que seriam reduzidos para 763 mil em 1940 por causa da febre amarela.

Do levantamento de 1934, é possível ver que São Paulo, capital, centralizava a da população do estado. Seguia-se Santos, com mais de 130 mil habitantes em sua parte urbana e depois Campinas, 
com cerca de 73 mil. Ribeirão Preto, em torno de 42 mil, e Sorocaba, com uma população urbana de 39 mil pessoas, eram os únicos núcleos restantes que ultrapassavam a cifra de 30 mil. Depois viriam Jundiaí, Piracicaba, Araraquara, Bauru, Taubaté e São Carlos, todas com mais de 20 mil (NEGRI, GONÇALVES E CANO, 1988).

A comunicação entre os centros científicos era rápida, um tanto devido ao telégrafo. A difusão das novas tecnologias e seu aperfeiçoamento também acontecia numa velocidade que nunca tinha acontecido antes. Ao final do processo, nos anos 30, o cenário que se apresenta é do território praticamente todo eletrificado, a indústria em expansão e o predomínio do capital americano no setor, dominando o mercado. Pode-se dizer então, que o quadro proposto para a pesquisa está completo: o estado está eletrificado e o modo de vida moderno, urbano e industrial praticamente consolidado como modelo a ser almejado no estado.

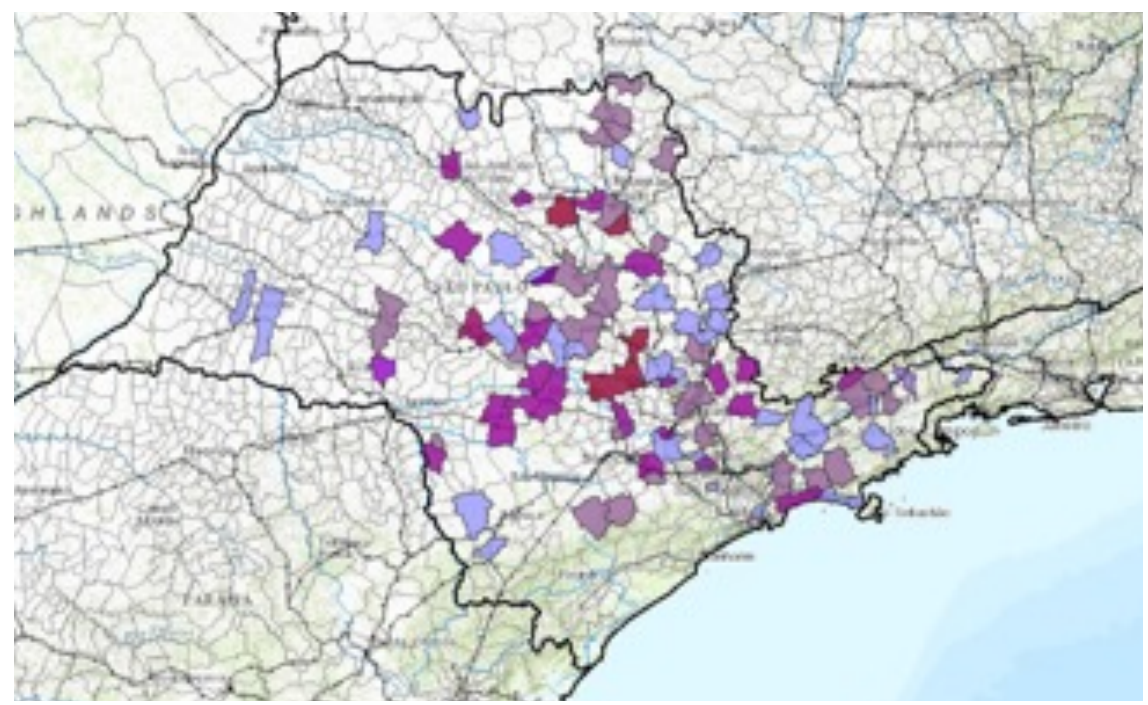

Figura 12. Centrais hidrelétricas que surgiram de 1890 a 1940 no estado sobreposto ao de ferrovias. Fonte: mapa elaborado no ODR, 2014.

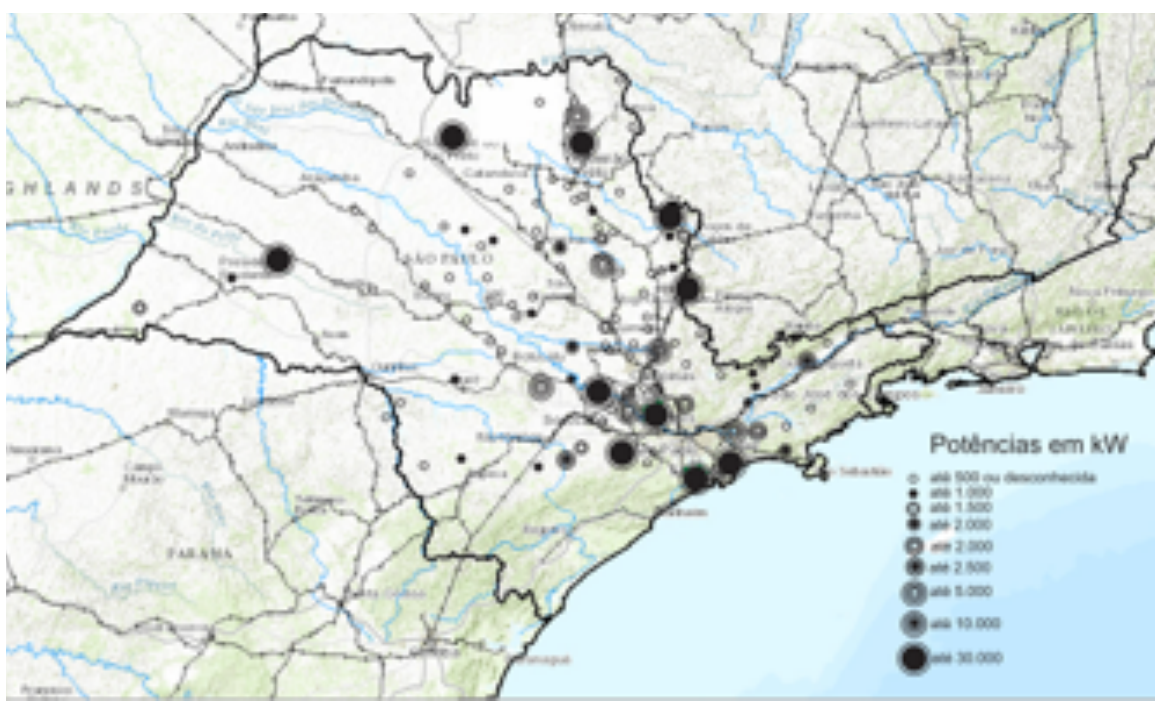

Figura 13. Potência das usinas hidrelétricas com a qual iniciaram as operações no estado de São Paulo - de 1890 a 1930. Muitas dessas já haviam sido repotencializadas em 1930. Fonte: mapa elaborado no ODR, 2014.

\section{Conclusões}

O complexo cafeeiro levou à criação e urbanização de cidades por todo o estado de São Paulo; estruturou a rede urbana paulista, por assim dizer, definindo sua hierarquia; possibilitou a formação de um excedente econômico que foi investido na implantação da malha ferroviária paulista e na construção do espaço 
urbano; impulsionou o trabalho livre e remunerado, criando mercado; e contraditoriamente, criou mecanismos para a superação deste padrão de acumulação, lançando as bases para o modo de produção urbano industrial.

A cidade que surge no fim do século XIX é a negação do rural, a negação da cidade colonial. Assim, os primeiros empresários do setor de energia no Brasil estão mais ligados à ferrovia e às fazendas de café do que com a indústria. Num segundo momento, todos esses empresários já são industriais também.

Do ponto de vista da arquitetura e do urbanismo, a geração de energia hidrelétrica possibilitou importantes inovações na forma e na vida urbana: novas máquinas domésticas que resultaram em novos usos das residências; novos equipamentos urbanos, como a iluminação pública, o transporte público, o cinema, a vida noturna etc.

A disponibilidade de energia também impulsionou a indústria nascente e com ela surgem distritos industriais, vilas operárias e núcleos fabris, difundindo novos padrões de moradias, novas formas de vida e de relação entre casa e espaços de uso coletivo.

As usinas hidrelétricas revelam o status da cidade em relação ao território, mas não são fator de expansão do mesmo. São muito mais um fator de indução urbana e expansão da porção industrial da cidade.

A trajetória da ferrovia no estado de São Paulo é quase idêntica a da energia, com a diferença que acontece 20 anos antes, mobiliza maiores capitais e investimentos, além de empresas mais poderosas que as de energia. A energia segue os caminhos das ferrovias, ou em outras palavras, "vai atrás do trilhos". Isso não foi uma coincidência. Muitas vezes os personagens são os mesmos.

Pode-se dizer que a trajetória da energia hidrelétrica no estado de São Paulo segue a da ferrovia que, como se sabe, segue a do café (ARGOLLO FERRÃO, 2004). Os caminhos desenhados pelas ferrovias seguem da capital para o oeste, com de dez anos de antecedência em média às usinas hidrelétricas, levando a modernidade e escoando o capital, transformando as vilas coloniais em cidades progressistas.

A ferrovia no interior paulista também partiu da pressão e da mobilização de cafeicultores que precisavam escoar a produção de café e dessa forma trouxeram engenheiros, companhias e tecnologia importada da Europa e Estados Unidos para implantá-las.

Finalmente, cabe salientar que a paisagem paulista vem se transformando continuamente desde que o processo de urbano-industrialização ganhou impulso com a implantação da energia hidrelétrica, ao partir do final do século XIX. O patrimônio correspondente a essa paisagem em permanente transformação constitui importante legado da indústria, cultura e natureza paulista, em particular, procuramos ressaltar a importância do patrimônio das usinas hidrelétricas de São Paulo.

\section{Referências}

AMARAL e PRADO(org.). Pequenas centrais hidrelétricas no Estado de São Paulo. São Paulo: Páginas \& Letras Editora e Gráfica, 2000.

ARGOLLO FERRÃO, A. M.; VALDERRAMA, B. V. B.; MORTATI, D. M. A. N.; MORAES, E. G.. 0 caso da Fazenda Ermida em Jundiaí [SP]: contribuição do café na configuração da paisagem cultural. Labor \& Engenho, Campinas [SP], Brasil, v.2, n.1, p.52-61, 2008. Disponível em: http://www.conpadre.org. Acesso em 15 jan. 2009.

ARGOLLO FERRÃO, André Munhoz de. Arquitetura do café. Campinas: Editora da Unicamp; São Paulo: IMESP, 2004.

ARGOLLO FERRAO, André Munhoz de. Arquitetura rural e o espaço não-urbano. Labor \& Engenho, Campinas, v. 1, n. 1, p.89-112, 2007. Disponível em: http://www.conpadre.org . Acesso em: 14 jan. 2009. 
BRASIL. Ministério da Integração Nacional. Secretaria de Desenvolvimento Regional. ODR Observatório de Desenvolvimento Regional. Brasília: MI, 2014. Disponível em: http://odr.mi.gov.br . Acesso em out. 2014.

CENTRO DA MEMÓRIA DA ELETRICIDADE NO BRASIL. Panorama do setor de energia elétrica no Brasil. Rio de Janeiro: CMEB, 1988.

DE LORENZO, Helena Carvalho. Eletrificação, urbanização e crescimento industrial. Tese (Doutorado). Instituto de Geociências e Ciências Exatas. UNESP. Rio Claro: UNESP, 1993.

FUNDAÇÃO PATRIMÔNIO HISTÓRICO DA ENERGIA DE SÃO PAULO. set. 2008.

http://www.museudaenergia.gorg.br . Acesso em 08 set. 2010.

FUNDAÇÃO SEADE, Repartição de Estatística e Arquivo do Estado de São Paulo. Anuário Estatístico de São Paulo (Brazil). 1901 a 1928.

HOMEM, Maria Cecília Naclério. o Palacete Paulistano e outras formas de morar da elite cafeeira: 1867-1918. São Paulo: Martins Fontes, 1996.

IBGE, 2012. CENSO 1920. http://www.censo2010.ibge.gov.br/dimensoes.php . Acesso em 05 set. 2012.

LEMOS, Carlos A.C.. A energia elétrica e a vida cotidiana em São Paulo. Assentamentos humanos, energia elétrica e vida cotidiana. 21 out. 1986. $1^{\circ}$ Seminário Nacional de História e Energia. Anais. Vol II. CESP, 1986.

MARANHÃO, Ricardo. CPFL 90 anos de história. São Paulo: DBA Artes Gráficas, 2002.

MORTATI, D. M. de A. N.; ARGOLlO FERRÃO, A. M. de. 0 surgimento das Pequenas Centrais Hidrelétricas e o processo de urbanização no interior de São Paulo (1890-1930). Labor \& Engenho, Campinas [Brasil], v. 5, n.2, p.26-44, 2011a. Disponível em: http://www.conpadre.org . Acesso em 10 set. 2012.

MORTATI, Débora M.A.N; ARGOLLO FERRAO, André M. Considerações dobre tipo, tipologia e a arquitetura das primeiras usinas hidrelétricas do Brasil. II Encontro Nacional Sobre Patrimônio Industrial. Centro Universitário Belas Artes, São Paulo, 2009b. TICCIH-Brasil.

MORTATI, Débora Marques de Almeida Nogueira. A implantação da hidroeletricidade e o processo de ocupação do território no interior paulista (1890-1930). 2013. 341 f. Tese (Doutorado em Engenharia Civil) - Faculdade de Engenharia Civil, Arquitetura e Urbanismo, Universidade Estadual de Campinas, Campinas [SP], 2013.

MORTATI, Débora Marques de Almeida Nogueira; ARGOLLO FERRAO, André Munhoz de, 2009. 0 patrimônio das Pequenas Centrais Hidrelétricas no contexto da economia cafeeira: o caso da Usina Hidrelétrica do Monjolinho em São Carlos, SP, Brasil (1893-1910) in II ENCUENTRO INTERNACIONAL DE PATRIMONIO INDUSTRIAL AGROALIMENTARIO, 2009a, Córdoba. [ANAIS] [1].

NEGRI, Barjas; GONÇALVES, Maria Flora; CANO, Wilson. O processo de Interiorização do Desenvolvimento e da Urbanização no Estado de São Paulo (1920-1980) in CANO, Wilson (coord). A interiorização do desenvolvimento econômico no Estado de São Paulo, 1920-1980. Vol. 1, n.1. São Paulo: SEADE, 1988.

SAES, F.A.M.. História \& Energia: a chegada da Light. São Paulo: Patrimônio Histórico/Eletropaulo, 1986. 